\title{
Evaluation of the quality of teaching mediation in a university environment
}

\author{
Avaliação da qualidade da mediação docente em
}

ambiente universitário

\section{Evaluación de la calidad de la mediación docente en el} ambiente universitario

WAGNER BANDEIRA ANDRIOLA (Da

\begin{abstract}
${ }^{\mathrm{b}}$
In Reuven Feuerstein's Cognitive Structural Modifiability Theory, 12 dimensions characterize teacher mediation, four of them are universal: intentionality and reciprocity; transcendence; meaning; awareness of modifiability. To validate the instrument aimed at evaluating the quality of teaching mediation, a sample of 531 undergraduates from 12 undergraduate courses, whose average age was 22.5 years (standard deviation 3.6 years), with a gender predominance $(n=309$ or $58.2 \%)$ and the majority came from baccalaureate $(n=359$ or $67.6 \%)$. The results showed a factorial structure in which the 26 assertions of the instrument were grouped into the four universal factors, with very high indexes of validity (selfvalues between 1.33 and 9.14, explained variance between 5.13\% and $35.15 \%$ ) and reliability (Cronbach's alphas between 0.71 and 0.91 ). The analysis of Variance (ANOVA) detected significant differences in the quality of teacher mediation of the courses in the areas of Human Sciences, Health Sciences and Technology in three of the universal factors $(F=12.96 ; p<0.001$ - Factor intentionality and reciprocity; $F$ $=5.42, p<0.001$ - Factor transcendence, $F=13.40, p<0.001$ - Factor awareness of the modifiability). It is concluded that the instrument has a high degree of
\end{abstract}

\footnotetext{
a Universidade Federal do Ceará (UFC), Fortaleza, CE, Brasil. Doutor em Filosofia e Ciências da Educação, e-mail:wagner.andriola@pq.cnpq.br

b Research funded by the National Council for Scientific and Technological Development (CNPq) - Process \#300878/2013-3 (Productivity Research Grant).
} 
confidence and validity, and can be used to evaluate the quality of teacher mediation in a university environment.

Keywords: Higher Education. Educational Evaluation. Factor Analysis. Learning Mediation. Cognitive modifiability.

\section{Resumo}

Na Teoria da Modificabilidade Estrutural Cognitiva de Reuven Feuerstein, a mediação docente caracteriza-se por 12 dimensões, sendo quatro destas universais: intencionalidade e reciprocidade; transcendência; significado; consciência da modificabilidade. Para validar o instrumento voltado a avaliar a qualidade da mediação docente, realizou-se pesquisa com amostra de 531 universitários de 12 cursos de graduação, com idade média de 22,5 anos (desvio padrão 3,6 anos), predominância do gênero feminino ( $n=309$ ou 58,2\%) e cursando bacharelados ( $n=$ 359 ou 67,6\%). Os resultados revelaram estrutura fatorial na qual as 26 assertivas do instrumento foram agrupadas nos quatro fatores universais, com índices muito elevados de validade (autovalores entre 1,33 e 9,14; variância explicada entre 5,13\% e 35,15\%) e de fiabilidade (alfas de Cronbach entre 0,71 e 0,91). A Análise de Variância (ANOVA) detectou diferenças significativas na qualidade da mediação docente dos cursos das áreas das Ciências Humanas, Ciências da Saúde e Tecnologia em três dos fatores universais ( $F=12,96 ; p<0,001$ - Fator intencionalidade e reciprocidade; $F=$ 5,42; $p<0,001$ - Fator transcendência; $F=13,40 ; p<0,001$ - Fator consciência da modificabilidade). Conclui-se que o instrumento possui elevado grau de confiança e de validade, podendo ser utilizado para avaliar a qualidade da mediação do professor em ambiente universitário.

Palavras-chave: Ensino Superior. Avaliação Educacional. Análise Fatorial. Mediação da Aprendizagem. Modificabilidade Cognitiva.

\section{Resumen}

En la Teoría de la Modificabilidad Estructural Cognitiva de Reuven Feuerstein, la enseñanza de la mediación se caracteriza por 12 dimensiones, cuatro de las cuales son universales: intencionalidad y reciprocidad; trascendencia; sentido; conciencia de la modificabilidad. Para validar el instrumento orientado a evaluar la calidad de la mediación docente, se realizó una encuesta con una muestra de 531 estudiantes universitarios de 12 carreras de grado, cuya edad promedio fue de 22,5 años (desviación estándar 3,6 años), con predominio de género. mujeres ( $n=309$ o 58,2\%) y la mayoría procedente de licenciaturas ( $n=359$ o 67,6\%). Los resultados obtenidos revelaron una estructura factorial en la que las 26 afirmaciones del instrumento se agruparon en los cuatro factores universales, con índices de validez muy altos (autovalores entre 1,33 y 9,14; varianza explicada entre 5,13\% y 35,15). \%) y fiabilidad (alfa de Cronbach entre 0,71 y 0,91). El Análisis de Varianza (ANOVA) detectó diferencias 
significativas en la calidad de la mediación docente en los cursos de las áreas de Ciencias Humanas, Ciencias de la Salud y Tecnología en tres de los factores universales ( $F=12,96 ; p<0,001$ - Factor de intencionalidad y reciprocidad; $F=5,42 ; p<0,001$ factor de trascendencia; $F=13,40 ; p<0,001$ - factor de conciencia de modificabilidad). Se concluye que el instrumento tiene un alto grado de confianza y validez y puede ser utilizado para evaluar la calidad de la mediación docente en un entorno universitario.

Palabras-clave: Enseñanza Superior. Evaluación Educativa. Análisis Factorial. Mediación del Aprendizaje. Modificabilidad Cognitiva.

Educate children and there is no need to punish men (Pythagoras).

\section{Introduction}

One of the bordering areas between Psychology and Neurology is the Neuropsychology. In this, the concept of mediator is fundamental for understanding some of its theoretical assumptions, among which the mediation, which is used to denote the information transmission action realized by the neurotransmitters in the neural network (ROT'TA; OHLWEILER; RIESGO, 2016). The clarity of this concept is fundamental for understanding the processes involved in the execution of the act of thinking. The present theoretical reflection is based on the similarity between the electrochemical process that allows the neurotransmission, and the teacher's pedagogical action that allows learning. Therefore, there will only be learning if there are neurotransmission processes (neurological foundation) resulting from the teaching approach and action (pedagogical foundation), enriched by metacognitive processes (BROWN, 1987). Under this perspective, it takes over the concept of mediator that, according to the optics in Neurology, is a function of neurotransmitters, chemical substances whose main action occurs in the connections between one neuron and another, or between one neuron and one muscle or glandular cell, allowing the transmission of nerve impulses (ARDILA, 2008). Transcending from Neurology to Psychology, the relevance of this mechanism (of mediation) is glimpsed to understand the learning process, because the essence of the learning act is in its own construction of information, of concepts and theories which should enable the generation of new 
knowledge managed by metacognitive processes, whereupon the mediator is vital (BROWN; CAMPIONE; DAY, 1981).

Therefore, in Education, the mediation is a special type of interaction between someone who teaches (the mediator) and someone who learns (the mediated). According to Belmonte (2003), this interaction must be characterized by an intentional and planned interposition of the mediator, acting between external sources of stimulus (the school) and the apprentice. Under this prism, the mediator must select, shape, focus, intensify the stimuli and feedback the apprentice in relation to their experiences, in order to produce meaningful learning, intensifying one's changes (FEUERSTEIN; FEUERSTEIN; FALIK, 2015).

Therefore, the mediation is a relevant strategy for the teacher to lead students to the development of superior competences and skills, such as the act of thinking critically. To this end, it must indicate paths that can lead to problem solving, guiding the student in reformulating hypotheses so that they are contrasted with the empirical reality and, later, confronted with the social reality, so that valid conclusions can be obtained and with a minimum of reflective thinking about the social impacts of generated scientific knowledge.

The task of teaching will entail the establishment of a full and constant relationship involving the mediation of the teacher with respect to students, with the aim of boosting curiosity, scientific interest and the spirit of search, imagination and autonomy. Therefore, mediation takes on a pedagogical strategy that is most relevant to the school context, especially focused on the teaching and learning process.Because it is a special form of interaction, the mediation incorporates some characteristics that particularize it. According to Reuven Feuerstein's Theory of Cognitive Structural Modifiability, there are 12 main characteristics or mediation dimensions. However, four of these dimensions are designed by Feuerstein (1994) as "universal", in other words, are always present in a mediated act: intentionality and reciprocity; transcendence; meaning; modifiability awareness. If these four characteristics are part of an interaction between at least two individuals, there is already an authentic mediation. Notwithstanding, for an even more effective and higher-quality mediation, it is necessary that the other characteristics or dimensions are also present (FEUERSTEIN; KLEIN; TANNENBAUM, 1994). 


\section{Ideal characteristics of teacher mediation}

Reuven Feuerstein theorized the existence of 12 dimensions involved in mediation, such as:

1. To have intentionality and reciprocity: the mediator must aim to teach and, through he's actions, to ensure that what is being taught is truly being learned. It is not merely the statement of a teaching goal, but a position statement on the mediator's part in which he, consciously, assumes responsibility for putting into practice the strategies at his disposal to ensure the achievement of goals and objectives. The reciprocity guarantees the establishment of certain complicity: the mediated subject must want to learn. Thereby, the reciprocity, part of the "didactic contract", is that enables learning. If the subject does not want to learn, the teacher's continuous efforts to help the student build the knowledge are useless. Therefore, the reciprocity should also be one of the objectives to achieve by the mediator. This must provoke this posture in its students. It should awaken student's desire to learn.

Intentionality and reciprocity are, according to the theory's author, the main conditions for an interaction to acquire the connotation of a mediation (SÁNCHEZ, 1992). The mediator's intentionality must share with the mediated in order to make him aware of it. It is interesting to highlight here the metacognitive processes that are expected to develop in the cognoscent subject:

The metacognitive processes form an important part of mediated interaction, allowing self-reflection, insight, and articulation between the whole and its component parts. This orientation, once internalized, becomes a powerful tool for more efficient learning, therefore, leads to higher levels of modifiability (FEUERSTEIN; KLEIN; TANNENBAUM, 1994, p. 17).

2. To observe in a transcendent way: it is the mediator's conscious orientation to teach looking at the future, in other contexts, for situations beyond the "here and now". Teaching should not be punctual, restricted to a single situation or context, it needs to be applicable, it needs to be able to be useful and integrate to other conceptual structures, other knowledge, other moments of the apprentice's life and other contexts. The mediation of transcendence aims to help the student to develop metacognition so that is possible, from work, reflexion and interaction with 
the learning object, the generalization and abstraction aiming the construction of new concepts from those initially addressed in the classroom.

3. To discover meanings: according to Fonseca (1998), to mediate the meaning of what is taught is the essence of cultural transmission:

Without meanings, the cultural transmission from one generation to another would not be viable. Leaving individuals to the pure exploration of tasks will not allow them to reach the meanings; they must be guided in order to appropriate them. The mediator (psychologist or professor, reeducator or therapist) is in charge, and culturally committed, of transmitting meanings. Without such assignments, the learning tasks, by themselves, do not produce the desired cognitive modifiability (p. 71).

Children learn the "modus operandi" of a culture because their parents, or other people, give meaning to the actions and beliefs of the group to which they are inserted. These are the traditions repeatedly valued and revived. The denial of the past, or the lack of information about the past, makes the child to have a onedimensional "horizontal" view of life. Living the here-and-now. There is no life project, there is no memory and, therefore, the experience of the elderly is not valued.

When teaching a concept, a value, a way of doing, the adult not only explains the concept itself, but resizes it within a structure of values, beliefs and ideals allowing the child to understand the concept and the interrelationships he maintains with other concepts inserted in other contexts, theories or historical moments (DA ROS, 2002). To mediate the meaning is to build with the student the learning of concepts that transcend the objects, the concepts that are assigned to the object and which place it in a context. The attribution of meanings is a product of the cultural group, it is subjective. It is not proper to the object, it is not a characteristic of it.

4. To feel competent: one of the main characteristics in the healthy development of human being is the ability to look at himself and perceive himself as a competent person. Not only to be competent, must he feel competent. It is very common in the classroom for a student to give up an activity before even starting it just because he does not feel able to do it. Moreover, many times, a small incentive from the teacher is enough for the student to succeed. Unfortunately, attitudes that do not promote the sense of competence in the child are also found in school. Many of the evaluation systems or promotion at school is based only on the "final product". Give to the learner a feedback about his learning failures, his mistakes, his 
gaps, the distance it still needs to travel until it can be considered adequate. Such procedure does not contribute to the development of the competence sense, ends up promoting negative feeling (FEUERSTEIN; RAND, 1974).

5. To know how to regulate and control one's behavior: one of the main complaints of teachers facing the failure of their students through a task is that they were too impulsive. They did not even understand the activity and have already begun their resolution. Impulsiveness generates a large number of errors (ANDRIOLA, 2009b). However, the opposite behavior, to start too slow is also not suitable for student development. There are two poles in this type of behavior: the inbibition, in which the subject remains without action, is "stuck", stopped before the need of action; and the initiation, in which the subject begins to perform the action without any kind of reflection or planning. It is necessary that the subject develop his capacity to adapt to the activities, wisely estimating the right time to start executing a task. It cannot take too long, nor start too early (FEUERSTEIN; BOLIVAR, 1980).

Besides, during the activity, it is necessary for the subject to apply its energy, time and dedication in order to perform the task properly. This control does not develop on its own. It is fruit of mediation, of the positive interference of a person guiding the subject in the execution of his activities. To focus on the process allows the learner to perceive at what stage the task is going wrong, or being ineffective: in correctly capturing the data and objectives of the task, in performing this task or in presenting its results. Instead, informing the student that the product is "wrong" does not bring any useful information to the student regarding the clear construction of a clear awareness of the quality of their behavior, and, therefore, of the causes of their errors (ANDRIOLA; CAVALCANTE, 1999).

6. To learn to share: the behavior of sharing leads the individual out of his egoistic world and, on the other hand, also allows others to participate in their way of thinking and acting. Such behavior is strongly influenced by the cultural characteristics of a society. These different ways of dealing with sharing behavior influence not only a specific area of the subject, but even their personality (FEUERSTEIN, 1994; ANDRIOLA, 2001). It is through the behavior of sharing that the teacher can know the way of thinking of his students, their ideas, their opinions, their reasoning, their hypotheses, their errors and hits. Therefore, sharing 
should be encouraged and sought, because it is an adjunct to the student evaluation process. The teacher also needs to learn to share with his students. He needs to talk while he thinks, while creating, while solving problems, because so, the student is aware that the process of solving a problem or creating an activity is not the result of a superior intelligence that already, beforehand, knows all the answers, but is the result of a continuous action of hypothetical-deductive reasoning. This knowledge enables the student to imagine himself in the same process, imagine himself as someone who, while striving will lead to success (GOMES, 2002).

7. To promote individuation and psychological differentiation: the process of individuation represents the individual's need to become unique, special, differentiated from the other subjects with whom it comes into contact. Apparently, this criterion would be the opposite of the mediation of sharing, but this would be a superficial conclusion. The mediation of individuation allows the subject to constitute himself as an individual, separating himself from the symbioses built by maternal or paternal behavior during the first stages of life. In essence, individuation is the process of personal work, self-reflection, and self-knowledge, which occurs through relationships with other subjects. Fadiman and Frager (1986, p. 60) highlighted:

No one can become aware of his individuality unless he is intimately and responsibly related to his neighbor; he is not retreating into a selfish desert when he tries to find himself. He can only discover himself when he is deeply connected to someone and, in general, related to many individuals with whom he can compare himself and through whom he is able to discriminate himself.

Thus, the professor, aware of his responsibility in interacting with his students, may intentionally value individual differences as necessary characteristics for each one to construct his individuation process healthily. He should avoid any actions that may have a discriminatory character or, even, massif (TURRA, 2007).

8. To seek, stablish and conquer goals: it is relevant to give meaning to actions beyond the "here and now". Reuven Feuerstein states that learners who do not develop this search behavior, establishment and achievement of goals end up living in search of immediate gratification, without being able to control his impulsivity in the search for the immediate pleasure (FEUERSTEIN; RAND; HOFFMAN, 1979). Currently there are many about young people's lack of values, lack of goals in life and 
"disposable" character of their commitments and actions. Perhaps the way to teach them the meaning of life and of human values inherent in deeper relationship lies in the possibility of mediating the pursuit of goals in smaller actions, from early on, by then, as adolescents, to be able to choose values that transcend their immediate needs. School and teachers play a very important role in this work, in this mission to promote in the apprentices a vision of the future to come.

9. To seek innovation and complexity: our world is undergoing rapid technological transformations. Professionals who are not adapting and learning at all times can be left behind in innovations and changes. If the school forms citizens filled with content, but not able to adapt continuously, will fail itself as a useful institution for society. In the words of Feuerstein, Klein and Tannembaum (1994, p. 45):

The usual answer: "I've never seen, never heard or done this before" with which someone would be justified not to accept an unusual task could no longer be accepted in a society of discontinuous technology and culture. Instead, the answer "Let me see how I can learn to do this" represents the most appropriate, adaptive answer. A readiness to learn and a propensity to change from the known to the unknown is a vital requirement in a changing world.

The school can promote situations in which students feel challenged in the execution of their tasks. Therefore, when one wants to mediate the challenge, one must seek to tailor the activities in order to address the axes of familiarity and complexity. Students challenged to learn will certainly invest greater efforts in achieving learning objectives. The sense of challenge is linked to that of inner motivation.

10. To be aware of modifiability: the concept of modifiability does not imply the idea of limit, but movement, of transformation and, thereby, of development. One time, Feuerstein and Bolivar (1979, p. 95) asserted:

El concepto de modificabilidad quiere sustituir la noción tradicional de inteligencia humana. Esta "capacidad del individuo para usar la experiencia previa en su adaptación a situaciones nuevas" representa el potencial de aprendizaje humano, que se refleja en la disposición a modificar el comportamiento para adaptarlo mejor a situaciones familiares y nuevas.

The idea of modifiability is present throughout the work of Reuven Feuerstein and integrates the axiomatic structure of his theory. Notwithstanding, according to Turra (2007), the five axioms that must be considered in mediating the 
consciousness of modifiability are: a) All human beings are modifiable; b) This specific student I am educating can be helped to modify; c) I myself am a mediator able to help every student to change; d) I myself am modifiable; e) The society in which I am inserted can be modified by me or by any other individual inserted in it.

11. To choose for the optimistic alternative: this criterion of mediation must be well understood in order not to be confused with the "optimistic" behavior. Optimism is a hope that something positive can happen, however, the subject does not try to make it happen. He keeps waiting. Instead, the option for the optimistic alternative, or positive alternative is the choice for the alternative whose ability to "work", so that, then, to make every effort for this to happen. Feuerstein (1994) states that when a student opts for a pessimistic path, he does not strive, does not work, does not start the path of achieving the goals. Therefore, it is necessary that the teacher's behavior encourage the student to work, to strive. In addition, the path for the student to get involved in school activities implies on choosing the optimistic alternative. Choosing the optimistic alternative in all other life situations allows the subject to anticipate positive results.

12. To create a sense of belonging: the mediation of the feeling of belonging is influenced by the cultural environment (FEUERSTEIN, 1994). The international political scenario, especially in relation to conflicts, to wars, to revolutionary or liberation groups is the scene of very significant examples of the strength of the feeling of belonging. Fanaticism is an extreme of this feeling. Its consequences, unfortunately, are present in the story of humanity. On the other hand, it is this same feeling of belonging that makes possible the conquest of freedom.

\section{Research Objectives}

The general objective of the research was to carry out the validation of an instrument aimed at the diagnosis of the quality of mediation of the undergraduate teachers of Federal University of Ceará (UFC), in accordance to the 12 factors theorized by Reuven Feuerstein. As specific objectives, it was intended: (a) To stablish metric validity parameters and reliability of the instrument aimed at evaluating the quality of mediation of teachers in a university environment; (b) To 
compare the quality of teacher mediation of courses in the areas of Human Sciences, Health Sciences, Natural Sciences and Technology.

\section{Methodology}

Research Locus

The study was concluded at headquarters of the Federal University of Ceará (UFC) in the city of Fortaleza, in 12 undergraduate courses that represented the areas of Human Sciences, Health Sciences, Natural Sciences and Technology. The research proposal was approved by the UFC Ethics Committee (protocol No. 112.573/2019), according to the resolution of the National Health Council (CNS) No. 510/2016, which addresses the specific ethical care of studies with humans.

\section{Criteria for Choosing the Courses}

The following criteria were adopted for the selection of undergraduate courses:

a) Belonging to one of the three major areas of human knowledge, already mentioned;

b) Have obtained the two largest and the two smallest grades in the National Student Performance Examination (ENADE), in their respective area of expertise.

\section{Courses and Students Samples}

As a result of the adoption of the referred criteria, the Table 1 presents the 12 selected courses and the samples of students submitted to the study.

Table 1 - Description of courses and students samples

(continues)

\begin{tabular}{c|c|c|c|c}
\hline $\begin{array}{c}\text { Knowledge } \\
\text { area }\end{array}$ & Course & $\begin{array}{c}\text { ENADE's } \\
\text { grade }\end{array}$ & $\begin{array}{c}\text { Sample of } \\
\text { students per } \\
\text { course }\end{array}$ & $\begin{array}{c}\text { Percentage over the } \\
\text { total sample of students } \\
(\mathbf{n}=\mathbf{5 3 1})\end{array}$ \\
\hline \multirow{2}{*}{$\begin{array}{c}\text { Health } \\
\text { Sciences } \\
(\mathbf{n}=\mathbf{1 8 1})\end{array}$} & Pharmacy & 2 & 43 & 8,1 \\
\cline { 2 - 5 } & Odontology & 3 & 46 & 8,7 \\
\cline { 2 - 5 } & Medicine & 4 & 48 & 9,0 \\
\cline { 2 - 5 } & Nursing & 4 & 44 & 8,3 \\
\hline
\end{tabular}


Table 1 - Description of courses and students samples

(conclusion)

\begin{tabular}{c|c|c|c|c}
\hline $\begin{array}{c}\text { Knowledge } \\
\text { area }\end{array}$ & Course & $\begin{array}{c}\text { ENADE's } \\
\text { grade }\end{array}$ & $\begin{array}{c}\text { Sample of } \\
\text { students per } \\
\text { course }\end{array}$ & $\begin{array}{c}\text { Percentage over the } \\
\text { total sample of students } \\
\text { (n = 531) }\end{array}$ \\
\hline \multirow{2}{*}{$\begin{array}{c}\text { Natural } \\
\text { Sciences } \\
\text { and }\end{array}$} & Mathematics & 2 & 44 & 8,3 \\
\cline { 2 - 5 } $\begin{array}{c}\text { Technology } \\
\text { (n= 179) }\end{array}$ & $\begin{array}{c}\text { Architecture and } \\
\text { Urbanism }\end{array}$ & 5 & 48 & 9,0 \\
\cline { 2 - 5 } & Geography & 5 & 43 & 8,1 \\
\hline $\begin{array}{c}\text { Human } \\
\text { Sciences } \\
(\mathbf{n = 1 7 1 )}\end{array}$ & Social Sciences & 3 & 44 & 8,3 \\
\cline { 2 - 5 } & Philosophy & 3 & 44 & 8,3 \\
\cline { 2 - 5 } & Music & 5 & 42 & 8,8 \\
\hline & Pedagogy & 4 & 38 & 7,9 \\
\hline
\end{tabular}

Source: Authors (2020).

According to Table 1, the percentage of students ranged from $7.2 \%$ (Pedagogy course) to $9 \%$ (Medicine courses and Food Engineering), indicating, thus, homogeneity in the distribution of sectored samples (per course) in the composition of the total sample of students $(n=531)$. This number of students ( $\mathrm{n}$ $=531$ ) represented $2 \%$ of the universe of approximately 26.000 students regularly enrolled in the 126 presential undergraduate courses of the Federal University of Ceará (UFC), according to institutional data from 2015². Therefore, the 12 courses of the present study, from which come the 531 student participants, represented approximately $9,5 \%$ of the total number of presential courses of the UFC.

\section{Instrument of Data Collection}

The instrument used for the data collection was a scale designed to evaluate the quality of mediation of the university professor, composed by blocks of questions designed to assess the 12 aspects or dimensions directly related to teacher mediation, as proposed by Reuven Feuerstein.

\footnotetext{
${ }^{1}$ Taken from the website http://www.ufc.br/images/_files/a_universidade/ufc_em_numeros/ufc_em_numeros_2016_ 2015.pdf. Access in: July 01, 2017.
} 


\section{Procedure of Obtaining Data}

After the courses departments are informed about the research objectives and, obtained the respective authorization to carry it out, the fellows of Scientific Initiation of the National Council of Scientific and Technological Development $(\mathrm{CNPq})$ and the Coordination of Improvement of Higher Education Personnel (CAPES), under the coordination of a Higher Technical Support Fellow (ATS $\mathrm{CNPq}$ ), contacted the teachers, so that they could provide lecture hours for the application of the instrument in classes of at least 25 students. Confidentiality of the respondents' personal information was guaranteed, ensuring that these would not be transmitted or disclosed to third parties.

\section{Main Results Profile of the Study's Students}

The study had the participation of 531 students $(\mathrm{n}=531)$ from 12 undergraduate courses, of both genders (309 women and 222 men), with an average age of 22.4 years old (SD = 3.6 years old) and amplitude from 17 to 60 years old. The majority of the student attended baccalaureate courses ( $n=359$ or $67.6 \%$ ), although there was an expressive group attending undergraduate degrees $(n=172$ or $32.4 \%$ ).

\section{Metric Instruments Parameters Validity of Construct}

Initially, we must stand out, as relevant, that the number of respondents respects the ratio of 10:1 (number of subjects for each questionnaire number). This value is recommended for conducting a factorial analysis of exploratory type (ANDRIOLA, 2008; KAHN, 2006; PASQUALI, 1999), this is: with an instrument of 26 items would require at least 260 respondents. It is perceived, that this number was largely exceeded, since 531 subjects participated in the process. In this sense, for the validation of the instrument the exploratory factorial analysis (AFE) was used, performed with SPSS 
17.0. The purpose of the analysis was to determine the number of factors to retain in the initial solution, the number of items associated with them (from the respective factorial load) and the internal consistency of retained factors.

It was made, initially, an exploratory analysis of the data, to identify the existence of the underlying structure, from an initial matrix of correlations. The purpose of this correlation matrix is to reveal the magnitude of the association of a given variable in detriment of another observed variable. High correlations indicate that the variables involved are under the influence of the same factor or latent construct. However, reduced correlations indicate that the variables are not under the influence of the same factor or latent construct (ANDERSON, 1958; HARMAN, 1968). The determinant of this matrix must be greater than zero, since if it is not, there will be no analytical solution, because it defines whether given square matrix will enable an inverse matrix. It is emphasized that the non-invertible matrix is called a singular matrix and its occurrence indicates an unstable matrix system. The result found in the present study was determinant $=1.16$. Next, the Kaiser-Meyer-Oklin's Test (KMO) was calculated, which evaluates the existence of a sufficient number of significant correlations between the items for the use of factorial analysis, constituting an overall measure that indicates the strength of the relation between items by means of partial correlations that represent the correlation between each pair of items, after the linear effect of all other items. The measure of suitability of KMO sample should be greater than 0.70 , considered inadequate a sample with $\mathrm{KMO}$ inferior than 0.60. In the present case $\mathrm{KMO}=0.931(\mathrm{p}<0.001)$, indicating that the correlation matrix can be submitted to factorial analysis.

As mentioned above, the Factorial Analysis (AF) aims to find latent variables at a given set of variances, when investigating whether the covariance or correlations of a set of observed variables can be explained in a reduced number of unobserved constructs or common factors (PASQUALI, 1999). Therefore, the first task is to verify if the scales that define latent variables have reliability or reproducibility, so that the latent variables can be reproduced in future studies (EBEL, 1967; ANDRIOLA, PASQUALI, 1995). In this stage the Cronbach's Alpha was used to calculate the reliability of the measuring instrument, whose result indicated $\alpha=0.921$ for a set of 26 items, expressing high internal reliability of the scale to evaluate teacher mediation in university environment. 
Next, the factorial structure of the scale was examined through AF, using the method of Principal Components' extraction, followed by the rotation of factors, so that an initial factorial solution can be obtained on what was proposed to be evaluated by the instrument (four universal dimensions of teacher mediation). In this work the chosen rotation procedure was the Varimax, for distributing the loads of the variables by components eliminating the intermediate loads, so that it is clearly understood which component in which the load of variable is highest. Following the guidelines of Andriola (2009a), Blunch (2008), Brown (2006), Henson and Roberts (2006), Kahn (2006), Preacher and MacCallum (2003), the criteria for the retention of factors were: a) Factor with an eigenvalue equal to or greater than 1 (eigenvalue $\geq 1.0$ ); b) Factorial weight of items equal to or greater than 0.50 (factor loadings $\geq 0.50$ ); c) Percentage of variance explained by factors must be at least $40 \%$; d) Internal factor consistency must be equal to or greater than 0.70 ; e) Internal factor consistency should not increase if the item is eliminated; f) Each factor must be represented by at least three items.

Regarding the commonality of the items, it should be noted that this is the proportion of the variance of a variable observed in the extracted factors (RUIZ; SAN MARTÍN, 1992). Their estimates range from 0 to 1 , being that a high value of in that range indicates that the extracted factors explain high proportions of the variance of the observed variable. The Table 2 presents information derived from the factors' extraction.

Table 2 - Description of the items' communalities values before and after the extraction of the factors

\begin{tabular}{|l|r|r|r|r|r|}
\hline Item & $\begin{array}{c}\text { Initial } \\
\text { communality }\end{array}$ & $\begin{array}{c}\text { Communality } \\
\text { after the } \\
\text { extraction }\end{array}$ & Item & $\begin{array}{c}\text { Initial } \\
\text { communality }\end{array}$ & $\begin{array}{c}\text { Communality } \\
\text { after the } \\
\text { extraction }\end{array}$ \\
\hline $\mathbf{1 . 1}$ & 1.000 & 0.490 & 6.1 & 1.000 & 0.652 \\
\hline $\mathbf{1 . 2}$ & 1.000 & 0.517 & 6.2 & 1.000 & 0.703 \\
\hline $\mathbf{1 . 3}$ & 1.000 & 0.459 & 6.3 & 1.000 & 0.562 \\
\hline $\mathbf{2 . 1}$ & 1.000 & 0.445 & 7.1 & 1.000 & 0.499 \\
\hline $\mathbf{2 . 3}$ & 1.000 & 0.454 & 8.1 & 1.000 & 0.514 \\
\hline $\mathbf{3 . 1}$ & 1.000 & 0.654 & 8.2 & 1.000 & 0.504 \\
\hline $\mathbf{3 . 2}$ & 1.000 & 0.582 & 9.1 & 1.000 & 0.414 \\
\hline $\mathbf{3 . 3}$ & 1.000 & 0.611 & 9.2 & 1.000 & 0.472 \\
\hline $\mathbf{4 . 1}$ & 1.000 & 0.474 & 10.1 & 1.000 & 0.511 \\
\hline $\mathbf{4 . 2}$ & 1.000 & 0.507 & 11.1 & 1.000 & 0.550 \\
\hline $\mathbf{4 . 3}$ & 1.000 & 0.391 & 12.1 & 1.000 & 0.642 \\
\hline $\mathbf{5 . 1}$ & 1.000 & 0.413 & 12.2 & 1.000 & 0.604 \\
\hline $\mathbf{5 . 2}$ & 1.000 & 0.421 & 12.3 & 1.000 & 0.636 \\
\hline
\end{tabular}

Source: Authors (2020). 
According to the results, after the extraction of factors, the communalities of the 26 items ranged from values between 0.391 (item 4.3) to 0.703 (item 6.2), respecting, therefore, the idealized minimum value for the retention of the item in the factor: 0.30 (HENSON; ROBERTS, 2006). By this criterion, all items can be submitted to factorial analysis (BROWN, 2006). In Table 3 there are presented eigenvalues and the percentages of variance explained by each factor retained, before and after the rotation procedure.

Table 3 - Eigenvalues and percentages of variance explained, before and after the rotation of retained factors

\begin{tabular}{|c|c|c|c|c|c|c|c|c|c|}
\hline \multirow[t]{2}{*}{$\begin{array}{l}\text { Retained } \\
\text { factor }\end{array}$} & \multicolumn{3}{|c|}{ Initial eigenvalue } & \multicolumn{3}{|c|}{$\begin{array}{l}\text { Sum of the square of the charges } \\
\text { after the factorial extraction }\end{array}$} & \multicolumn{3}{|c|}{$\begin{array}{c}\text { Sum of the square of the charges } \\
\text { after the rotation of the } \\
\text { extracted factors }\end{array}$} \\
\hline & Total & $\begin{array}{c}\% \text { of } \\
\text { variance }\end{array}$ & $\begin{array}{c}\% \\
\text { accumulated }\end{array}$ & Total & $\begin{array}{c}\% \text { of } \\
\text { variance }\end{array}$ & $\begin{array}{c}\% \\
\text { accumulated }\end{array}$ & Total & $\begin{array}{c}\% \text { of } \\
\text { variance }\end{array}$ & $\begin{array}{c}\% \\
\text { accumulated }\end{array}$ \\
\hline 1 & 9.139 & 35.151 & 35.151 & 9.139 & 35.151 & 35.151 & 6.427 & 24.718 & 24.718 \\
\hline 2 & 1.764 & 6.784 & 41.935 & 1.764 & 6.784 & 41.935 & 2.830 & 10.885 & 35.603 \\
\hline 3 & 1.441 & 5.541 & 47.476 & 1.441 & 5.541 & 47.476 & 2.264 & 8.707 & 44.310 \\
\hline 4 & 1.334 & 5.129 & 52.606 & 1.334 & 5.129 & 52.606 & 2.157 & 8.295 & 52.606 \\
\hline
\end{tabular}

Source: Authors (2020).

Table 3 presents information from four extracted factors. Factor 1 explained initially $35.151 \%$ of the total variance (eigenvalue $=9.139$ ), completing the analytical process with $24.718 \%$ (eigenvalue $=6.427$ ). Factor 2 explained initially $6.784 \%$ of the total variance (eigenvalue $=1.764$ ), completing the analytical process with $10,885 \%$ (eigenvalue $=2.83$ ). Factor 3 explained initially $5.541 \%$ of the total variance (eigenvalue $=1.441$ ), completing the analytical process with $8.707 \%$ (eigenvalue $=2.264$ ). Finally, factor 4 explained initially $5.129 \%$ of the total variance (eigenvalue $=1.334)$, completing the analytical process with $8.295 \%$ (eigenvalue $=$ 2.157). These four factors explained together $52.606 \%$ of the total variance, before and after extraction and rotation of them. The next step of the data analysis involved the calculation of the factorial loads of the items in the rotated factors, as shown in Table 4. 
Table 4 - Factorial loadings of items on rotated factors

\begin{tabular}{l|r|r|r|r}
\hline \multirow{2}{*}{ Items } & \multicolumn{5}{|c}{ Factors and respective factor loads of items } \\
\hline & Factor 1 & Factor 2 & Factor 3 & Factor 4 \\
\hline $\mathbf{8 . 1}$ & 0.662 & & & \\
\hline $\mathbf{1 . 2}$ & 0.644 & & & \\
\hline $\mathbf{1 . 1}$ & 0.641 & & & \\
\hline $\mathbf{8 . 2}$ & 0.632 & & & \\
\hline $\mathbf{9 . 2}$ & 0.626 & & & \\
\hline $\mathbf{1 0 . 1}$ & 0.619 & & & \\
\hline $\mathbf{5 . 1}$ & 0.616 & & & \\
\hline $\mathbf{1 1 . 1}$ & 0.608 & & & \\
\hline $\mathbf{9 . 1}$ & 0.599 & & & \\
\hline $\mathbf{4 . 1}$ & 0.598 & & & \\
\hline $\mathbf{4 . 2}$ & 0.589 & & & \\
\hline $\mathbf{5 . 2}$ & 0.589 & & & \\
\hline $\mathbf{2 . 2}$ & 0.586 & & & \\
\hline $\mathbf{2 . 1}$ & 0.579 & & & \\
\hline $\mathbf{1 . 3}$ & 0.560 & & & \\
\hline $\mathbf{4 . 3}$ & 0.559 & & & \\
\hline $\mathbf{6 . 2}$ & & 0.786 & & \\
\hline $\mathbf{6 . 1}$ & & 0.761 & & \\
\hline $\mathbf{6 . 4}$ & & 0.686 & & \\
\hline $\mathbf{7 . 1}$ & & 0.574 & & \\
\hline $\mathbf{1 2 . 3}$ & & & 0.753 & \\
\hline $\mathbf{1 2 . 1}$ & & & 0.741 & \\
\hline $\mathbf{1 2 . 2}$ & & & 0.709 & \\
\hline $\mathbf{3 . 1}$ & & & & 0.786 \\
\hline $\mathbf{3 . 3}$ & & & & \\
\hline $\mathbf{3 . 2}$ & & & & \\
\hline & & & & \\
\hline
\end{tabular}

Source: Authors (2020).

Of the factorial loads of each item in the factor extracted and rotated, it is possible, now, the qualitative interpretation of what each factor represents. The grouping of 16 items in Factor 1, reveals itself as the intentionality and reciprocity dimension. This dimension of mediation has as its main peculiarity the fact that the mediator must consciously assume the responsibility for putting into practice the pedagogical strategies at their disposal, in order to guarantee the attainment of the established goals and educational objectives a priori. Reciprocity guarantees the establishment of a certain complicity of the apprentice, that is, the subject (mediated) must want to learn (or be motivated to do so) the content that will be approached by the mediator. Factor 2, composed by the grouping of four items, 
reveals itself as the transcendent dimension. This dimension portrays the mediator's conscious orientation in teaching by looking at other contexts, for situations beyond the "here and now", from disparate and sometimes conflicting opinions about a particular subject. Teaching should not be punctual, restricted to a single situation or context, it needs to be applicable, be useful and integral to other conceptual structures, other knowledge, other moments of the apprentice's life in other contexts, considering various opinions. The transcendence mediation aims to assist the student to develop metacognition so that it is possible, from work, reflection and interaction with the learning object, the generalization and abstraction. Factor 3, composed by the grouping of three items, expresses the meaning dimension, which portrays how subjects learn the "modus operandi" of a culture, because their parents or other people give meaning to the actions and beliefs of the group to which they are inserted. The lack of information about the past causes the individual to have an one-dimensional "horizontal" view of life. To mediate meaning is to build with the student the learning of concepts that transcend the object, of the concepts that are assigned to the object and which place it in a context. The attribution of meanings is a product of the cultural group. Finally, factor 4, which was also composed by the grouping of three items. This dimension is associated to the capacity to be aware of the modifiability, which expresses the idea of movement, of transformation and, therefore, of individual dynamic development. In relation to education, the teacher who believes in the student's ability to modify, to learn, to develop, can then choose a methodology loaded with positive efforts that allow the learner to try again, instead of giving up in the most difficult cases. This dimension uses the concept of brain plasticity.

\section{Reliability of the Measuring Instrument}

It must be demonstrated, now, the reliability of the instrument to measure the four dimensions previously mentioned (EBEL, 1967). For this, the value of Cronbach's alpha coefficient was determined for each of the factors underlying the instrument of measurement of teacher mediation in a university environment, besides the corrected correlation of each item with the total score. The values are presented in Table 5. 
Table 5 - Values of Cronbach's alpha in each of the four extracted factors

\begin{tabular}{|c|c|c|c|}
\hline $\begin{array}{c}\text { Factors and } \\
\text { values of } \\
\text { Cronbach's alpha }\end{array}$ & Items & $\begin{array}{l}\text { Item-total corrected } \\
\text { correlation }\end{array}$ & $\begin{array}{c}\text { Cronbach's alpha } \\
\text { (if the item is removed) }\end{array}$ \\
\hline \multirow{16}{*}{$\begin{array}{c}\text { Factor } 1 \\
(\alpha=0.91)\end{array}$} & 8.1 & 0.640 & 0.906 \\
\hline & 1.2 & 0.631 & 0.906 \\
\hline & 1.1 & 0.597 & 0.907 \\
\hline & 8.2 & 0.643 & 0.906 \\
\hline & 9.2 & 0.619 & 0.907 \\
\hline & 10.1 & 0.629 & 0.906 \\
\hline & 5.1 & 0.573 & 0.908 \\
\hline & 11.1 & 0.612 & 0.907 \\
\hline & 9.1 & 0586 & 0.908 \\
\hline & 4.1 & 0.600 & 0.907 \\
\hline & 4.2 & 0.632 & 0.906 \\
\hline & 5.2 & 0.583 & 0.908 \\
\hline & 2.2 & 0.603 & 0.907 \\
\hline & 2.1 & 0.510 & 0.910 \\
\hline & 1.3 & 0.578 & 0.908 \\
\hline & 4.3 & 0.567 & 0.908 \\
\hline \multirow{4}{*}{$\begin{array}{l}\text { Factor } 2 \\
(\alpha=0.79)\end{array}$} & 6.2 & 0.689 & 0.696 \\
\hline & 6.1 & 0.608 & 0.738 \\
\hline & 6.3 & 0.588 & 0.748 \\
\hline & 7.1 & 0.531 & 0.779 \\
\hline \multirow{3}{*}{$\begin{array}{l}\text { Factor } 3 \\
(\alpha=0.72)\end{array}$} & 12.1 & 0.524 & 0.661 \\
\hline & 12.2 & 0.535 & 0.651 \\
\hline & 12.3 & 0.579 & 0.594 \\
\hline \multirow{3}{*}{$\begin{array}{l}\text { Factor } 4 \\
(\alpha=0.71)\end{array}$} & 3.1 & 0.564 & 0.564 \\
\hline & 3.2 & 0.484 & 0.665 \\
\hline & 3.3 & 0.530 & 0.609 \\
\hline
\end{tabular}

Source: Authors (2020).

According to the data, Cronbach's alpha values ranged from 0.71 (Factor 4) to 0.91 (Factor 1), thus implying in the adequacy of reliability of the measuring instrument (internal consistency) to evaluate the constructs (factors) to which it proposes, which are: four universal factors present in the act of teacher mediation, as Reuven Feuerstein stipulated. The obtained values reveal, thus, high reliability of the referred instrument, according to the opinion of Hair et al. (2006). The values of the corrected correlations of the item with the total score revealed an amplitude from 0.484 (item 3.2) to 0,643 (item 8.2), highly significant magnitudes.

Finally, the values of Cronbach's alpha when the item is withdrawn did not undergo substantive changes in Factor 1, since this parameter's magnitude remained 
around 0.91 revealing, thus, high internal consistency. In the case of Factor 2, the magnitudes of Cronbach's alpha ranged from 0.70 (if item 6.6 were withdrawn) to 0.78 (if item 7.1 were withdrawn), remaining around the total observed value of 0.79 for the referred factor, revealing, in this way, moderate internal consistency. With regard to Factor 3, the magnitudes of Cronbach's alpha ranged from 0.59 (if item 12.3 were withdrawn) to 0.66 (if item 12.1 were withdrawn), revealing high sensitivity and dependence of this factor for their respective items. This particular behavior of Factor 3 explains the total value obtained by Cronbach's alpha: 0.72 (moderate internal consistency). A similar pattern was observed in Factor 4: the magnitudes of Cronbach's alpha ranged from 0.56 (if item 3.1 were withdrawn) to 0.67 (if item 3.2 were withdrawn), remaining around the total observed value of 0.71 for the referred factor (moderate internal consistency). Analyzing the results, either from factor analysis, or from the internal consistency, in light of the criteria for determining the four factors stablished according to Reuven Feuerstein's theory, we can affirm that the adaptation of the scale to evaluate the teacher mediation in the university has excellent psychometric qualities.

\section{Diagnosis of the Quality of Teacher Mediation}

In order to compare the mediation's quality provided by the teachers of courses in the areas of Human Sciences, Health Sciences, Natural Sciences and Technology, the Variance Analysis (ANOVA - one way) test was used for comparison between and inter-groups (ANDERSON, 1958). In Figure 1 there are the trends of the mean values of mediation in each of the four universal factors, according to the area of knowledge to which the respective teacher's course is linked. 
Figure 1 - Trends in the mean values of teacher scores in the Scale to Evaluate the Quality of Mediation, considering the Areas of the Human Knowledge

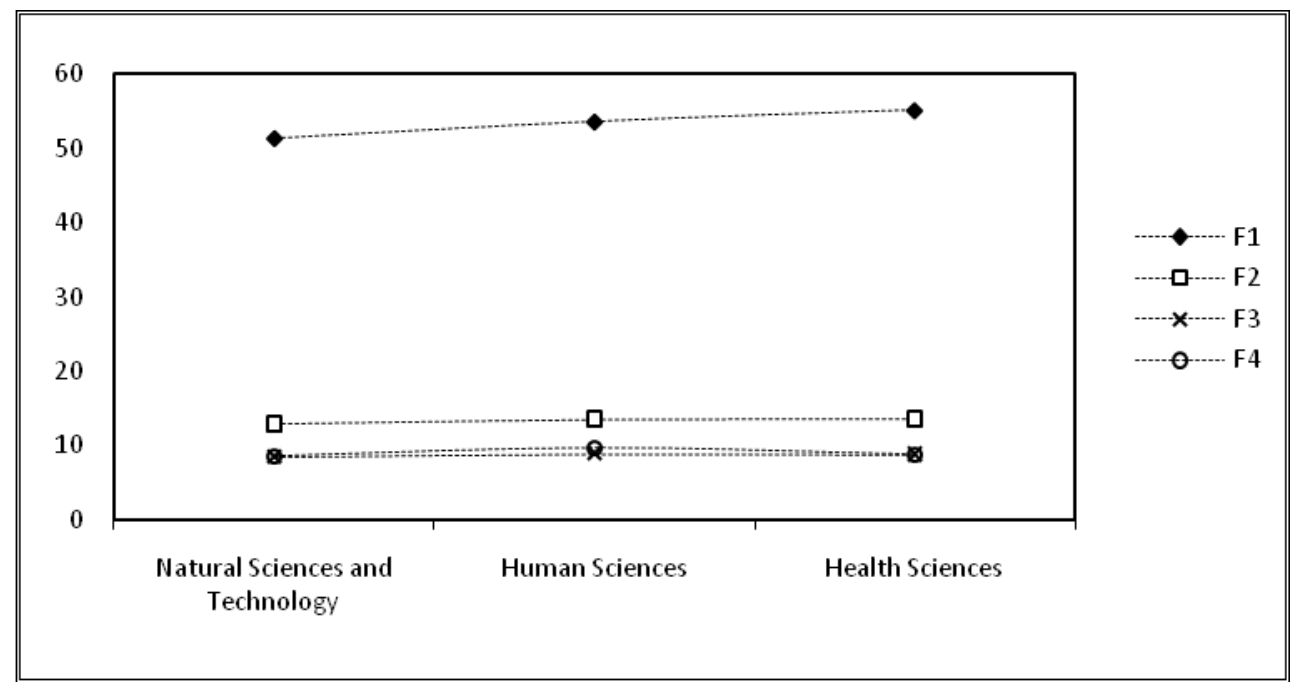

Source: Authors (2020).

According to data on Figure 1, the highest average in F1 (Factor 1) was obtained by the teachers linked to Health Sciences courses $(\mu=55.1$; SD $=6.4$ ), followed by the teachers of the courses related to Human Sciences $(\mu=53.6$; SD $=$ 5.8) and finally, teachers of the courses related to Natural Sciences and Technology $(\mu=51.4$; SD = 8.6). The ANOVA Test identified significant differences between these three averages $\left[\mathrm{F}_{(0.01 ; 2,528)}=12.96 ; \mathrm{p}<0.001\right]$ which made it possible to infer, thus, that there was better mediation of the teachers of the courses in the area of Health Sciences. Thereby, in the intentionality and reciprocity dimension, which has as main peculiarity the fact that the mediator must consciously assume the responsibility for putting into practice the pedagogical strategies at their disposal, in order to guarantee the attainment of the stablished goals and educational objectives a priori, as well as in establishing apprentice complicity, there was higher quality by the professors of the courses in the area of Health Sciences.

Still according to Figure 1, the highest average in F2 (Factor 2) was obtained by the teachers linked to the courses of Health Sciences $(\mu=13.6$; SD $=2.3)$, followed by the teachers of the courses related to Human Sciences $(\mu=13.5$; SD $=$ 2.1) and finally, teachers linked to the courses in Natural Sciences and Technology $(\mu=12.9 ; \mathrm{SD}=2.4)$. The ANOVA Test identified significant differences between these three averages $\left[\mathrm{F}_{(0.01 ; 2,528)}=5.42 ; \mathrm{p}<0.005\right]$ which made it possible to infer, 
thus, that there was better mediation of the teachers of the courses in the area of Health Sciences. Thereby, regarding the transcendence dimension, which portrays the mediator's conscious orientation in teaching by looking at other contexts, to situations beyond the "here and now", from disparate and sometimes opposing opinions about a particular subject, there was higher quality, once again, of teachers of the courses in the area of Health Sciences.

Regarding Factor 3 (F3), the highest average was obtained by the teachers linked to the courses of Human Sciences $(\mu=8.9$; SD $=2.0)$, followed by the teachers of the courses related to Health Sciences $(\mu=8.8$; SD $=2.3)$, and finally the teachers linked to courses of Natural Sciences and Technology $(\mu=8.5$; SD $=$ 2.1). The ANOVA Test did not identify significant differences between these three averages $\left[\mathrm{F}_{(0.01 ; 2,528)}=1.50 ; \mathrm{p}=0.223\right]$ which made it possible to infer, in this way, that there were no qualitative differences in teacher mediation regarding the mediation of meaning. Therefore, it seems that all teachers, regardless of the area of human knowledge, are able to build with the student the learning of concepts that transcend the object, of the concepts that are attributed to the object and that inserts it in a given socio-historical context. The attribution of meanings is the product of the cultural group, it is subjective. It is not proper to the object, it is not characteristic of it.

Finally, regarding Factor 4 (F4), the highest average was obtained by the teachers linked to the courses of Human Sciences $(\mu=9.7 ; \mathrm{SD}=1.6 ; \mathrm{n}=171)$, followed by the teachers of the courses related to Health Sciences $(\mu=8.9$; SD $=$ $1.9 ; \mathrm{n}=181$ ), and finally the professors linked to the courses of Natural Sciences and Technology $(\mu=8.7 ; \mathrm{SD}=2.0 ; \mathrm{n}=179)$. The ANOVA Test identified significant differences between these three averages $\left[\mathrm{F}_{(0.01 ; 2,528)}=13.4 ; \mathrm{p}<0.001\right]$, which made it possible to infer, this way, that there was better mediation of the teachers of the courses in the Human Sciences area. Thereby, regard the ability to be aware of the modifiability, which expresses the idea of movement, of transformation and, therefore, of individual dynamic development; of the teacher's belief in the student's ability to change, to learn, to develop; the professors of the courses in the area of Human Sciences were superior to the colleagues of the other two areas of human knowledge. 


\section{Final Considerations}

The main objective of this scientific work consisted in determining the metric parameters of factorial validity and reliability of an instrument to evaluate the quality of teaching mediation in a university environment, whose theoretical basis is the Theory of Cognitive Structural Modifiability, proposed by Reuven Feuerstein. Understanding mediation as a pedagogical strategy that is most relevant to the school context, especially focused on the teaching and learning process, the present study provided the validation of an instrument with the purpose of evaluating this important aspect among university professors.

To validate the instrument aimed at evaluating the quality of teaching mediation, a survey was carried out with 531 university students from 12 undergraduate courses of an IES. The results revealed a factorial structure in which the 26 instrument assertions were grouped into the four universal factors, as theorizes: intentionality and reciprocity; transcendence; mediation of meaning; modifiability awareness, whose eigenvalues varied between 1.33 and 9.14. The variance explained by the four factors mentioned above ranged from $5.13 \%$ to $35.15 \%$. Regarding the reliability or reliability parameter or trustworthiness, the values for Cronbach's alpha coefficients ranged from 0.71 to 0.91 . Therefore, it seems very reasonable to say that this instrument can be used with great confidence to evaluate teacher mediation in university. However, we consider it fundamental to continue the studies that deepen the factorial validity of this measuring instrument with a view to proceeding with the confirmatory analysis. Finally, regarding the quality of teaching mediation of courses in the areas of Human Sciences, Health Sciences and Technology, there were significant differences in three of the universal factors: intentionality and reciprocity (higher quality provided by Health Sciences teachers); transcendence (higher quality provided by Health Sciences teachers); modifiability awareness (higher quality provided by Human Sciences teachers). In the factor mediation of meaning no significant differences were detected between the three main areas of knowledge. To conclude the importance of the quality of teaching mediation in a university environment, through the activities of teaching and research, it is opportune to highlight a wise sentence uttered by the greatest 
scientists of all time, the German physicist Albert Einstein: the mind that opens to a new idea never returns to its original size.

\section{References}

ARDILA, A. On the evolutionary origins of executive functions. Brain and Cognition, v. 68, p. 92-99, 2008.

ANDERSON, T. An introduction to multivariate analysis. New York: John Wiley \& Sons, 1958.

ANDRIOLA, W. B. Psicometria moderna: características e tendências. Estudos em Avaliação Educacional, São Paulo, v. 20, p. 319-340, 2009a.

ANDRIOLA, W. B. Planejamento Estratégico e Gestão Universitária como Atividades Oriundas da Auto-Avaliação de Instituições de Ensino Superior (IES): o Exemplo da Universidade Federal do Ceará (UFC). Revista Iberoamericana de Evaluación Educativa (Online), Santiago do Chile, v. 2, p. 82-103, 2009b.

ANDRIOLA, W. B. Uso da Teoria de Resposta ao Item (TRI) para analisar a equidade do processo de avaliação do aprendizado discente. Revista Iberoamericana de Evaluación Educativa, Santiago do Chile, v. 1, p. 171-189, 2008.

ANDRIOLA, W. B. Factores caracterizadores de centros educativos eficaces. Bordón: Revista de Pedagogia, Madrid, v. 53, n. 2, p. 175-183, 2001.

ANDRIOLA, W. B.; CAVALCANTE, L. R. Avaliação do raciocínio abstrato em estudantes do ensino médio. Estudos de Psicologia, Natal, v. 4, p. 23-37, 1999.

ANDRIOLA, W. B.; PASQUALI, L. A construção de um Teste de Raciocínio Verbal (RV). Psicologia: Reflexão e Crítica, Porto Alegre, v. 8, n. 1, p. 51-72, 1995.

BELMONTE, T. Elperfil del profesor mediador. Madrid: Editorial Santillana, 2003.

BLUNCH, N. J. Introduction to structural equations modeling using AMOS. Thousand Oaks (California): Sage Publications, 2008.

BROWN, T. Confirmatory factor analysis for applied research. New York: The Guiford Press, 2006.

BROWN, A. Metacognition, executive control, self-regulation, and other more mysterious mechanisms. In: WEINERT, F. E.; KLUWE, R. (Eds.). Metacognition, motivation, and understanding. Hillsdale, New Jersey: Lawrence Erlbaum Associates, 1987. p. 1-16.

BROWN, A.; CAMPIONE, J.; DAY, J. Learning to learn: On training students to learn from the texts. Educational Researcher, v. 10, p. 14-21, 1981.

DA ROS, S. Z. Pedagogia e mediação em Reuven Feuerstein. São Paulo: Plexus, 2002.

EBEL, R. Principles of Educational and Psychological Measurement. Chicago, IL: Rand and Mcnally \& Company, 1967. 
FADIMAN, J.; FRAGER, R. Teorias da personalidade. São Paulo: Harbra, 1986.

FEUERSTEIN, R. Inteligência se aprende. Revista Isto É, n. 1297, p. 5-6, 1994.

FEUERSTEIN, R.; FEUERSTEIN, R.; FALIK, L. Beyond Smarter: Mediated Learning and the Brain's Capacity for Change. New York, NY: Teachers College Press, 2015.

FEUERSTEIN, R.; BOLIVAR, C. R. La teoria de la modificabilidad cognoscitiva estructural: una explicación alternativa sobre el desarrollo cognoscitivo diferencial. Guayana: Universidad Nacional Experimental de Guayana, 1980.

FEUERSTEIN, R.; KLEIN, P.; TANNEMBAUM, A. Mediated Learning Experience (MLE): Theoretical, Psychosocial and Learning Implications. London: Freund, 1994.

FEUERSTEIN, R.; RAND, Y. Mediated learning experience: An outline of the proximal typology for differential development of cognitive functions. Baltimore: University Park Press, 1974.

FEUERSTEIN, R.; RAND, Y.; HOFFMAN, M. The dynamic Assessment of Retarded Performance: The Learning Assessment Device, Theory Techniques. Glenview, IL: Scott, Foresman \& Company, 1979.

FONSECA, V. Aprender a Aprender: a Educabilidade Cognitiva. Porto Alegre: Artes Médicas, 1998.

GOMES, C. M. A. Feuerstein e a construção mediada do conbecimento. Porto Alegre: Artmed Editora, 2002.

HARMAN, H. Modern Factor Analysis. Chicago, London: The University Chicago Press, 1968.

HAIR, J. et al. Multivariate data analysis. New Jersey: Pearson Educational, 2006.

HENSON, R.; ROBERTS, K. Use of exploratory factor analysis in published research. Common errors and some comment on improved practice. Educational and Psychological Measurement, v. 66, n. 3, p. 393-416, 2006.

KAHN, J. Factor analysis in counseling psychology. Research, training, and practice: Principles, advances and applications. The Counseling Psychologist, v. 34, n. 5, p. 684-718, 2006.

PASQUALI, L. Análise fatorial: um manual teórico-prático. Brasília: Editora UnB, 1999.

PREACHER, K.; MacCALLUM, R. Repairing Tom Swift's electric factor analysis machine. Understanding Statistics, v. 2, n. 1, p. 13-43, 2003.

ROTTA, N.; OHLWEILER, L.; RIESGO, R. Transtornos da aprendiragem: abordagem neurobiológica e multidisciplinar. Porto Alegre: Artmed, 2016.

RUIZ, M. Á.; SAN MARTÍN, R. Una simulación sobre el comportamiento de la regla K1 en la estimacón del número de factores [The behavior of the K1 rule estimating the number of factors: A study with simulated data]. Psicothema, v. 4, n. 2, p. 543-550, 1992. 
SÁNCHEZ, M. D. P. La Modificabilidad Estructural Cognitiva y el Programa de Enriquecimiento Instrumental (P.E.I.). Madrid: Bruno, 1992.

TURRA, N. C. Reuven Feuerstein: experiência de aprendizagem mediada: um salto para a modificabilidade cognitiva estrutural. Educere et Educare, v. 2, n. 4, p. 297-310, 2007.

RECEBIDO: $29 / 11 / 2020$

RECEIVED: $11 / 29 / 2020$

RECIBIDO: $29 / 11 / 2020$

APROVADO: 28/01/2021

APPROVED: 01/28/2021

APROBADO: 28/01/2021 